\title{
Analisis Perilaku Penerimaan Penggunaan E-Filing Menggunakan Pendekatan Theory of Planned Behavior dan Technology Acceptance Model
}

\author{
Belli Kafilla Gani ${ }^{*}{ }^{*}$, Evi Dwi Wahyuni ${ }^{2}$, Gita Indah Marthasari ${ }^{3}$ \\ 1,2,3 Teknik Informatika/Universitas Muhammadiyah Malang \\ belliiceman@gmail.com ${ }^{* 1}$, evi.d.wahyuni@gmail.com², gita@umm.ac.id ${ }^{3}$
}

\begin{abstract}
Abstrak
Perpajakan telah menjadi persyaratan negara sebagai penyumbang devisa terbesar negara, perpajakan di Indonesia belum lolos berbagai kegiatan. Terutama di era modern ini, yang selalu menggunakan teknologi dalam pemenuhan kebutuhan sehari-hari, perpajakan di Indonesia kini juga telah mulai menerapkan sistem baru yang mulai mengedepankan teknologi, yaitu sistem pelaporan pajak tahunan berbasis online, sistem ini adalah sistem e-Filing. Penelitian ini mengacu pada seberapa banyak pengguna merasa puas dengan sistem e-Filing karena sistem ini merupakan sistem baru yang dimiliki oleh Direktorat Jenderal Pajak (DJP) sebagai langkah inovasi dan pembaharuan dalam penyampaian laporan pajak tahunan. Technology Acceptance Model (TAM) dan Theory of Planned Behaviour (TPB) adalah referensi peneliti sebagai sarana pendekatan dalam menganalisis sistem e-Filing karena Technology Acceptance Model (TAM) mengacu pada aspek penerimaan berbasis teknologi, sedangkan dalam Theory of Planned Behavior (TPB) mengacu pada aspek penerimaan berdasarkan perilaku pengguna dalam menggunakan sesuatu, Partial Least Square (PLS) digunakan untuk menghitung serta untuk melepaskan data sehingga dapat mengukur perilaku penerimaan pengguna dalam menggunakan Sistem e-Filing berdasarkan kombinasi dari dua model
\end{abstract}

Kata Kunci: Perpajakan, E-filing, TAM, TPB, PLS

\begin{abstract}
Taxation has become a state requirement as the country's largest foreign exchange contributor, taxation in Indonesia has not passed various activities. Especially in this modern era, which always uses technology in meeting daily needs, taxation in Indonesia has now also begun to implement a new system that began to put forward technology, namely an online-based annual tax reporting system, this system is an e-Filing system. This study refers to how many users feel satisfied with the e-Filing system because this system is a new system owned by the Direktoral Jenderal Pajak (DJP) as a step of innovation and renewal in the submission of annual tax reports. Technology Acceptance Model (TAM) and Theory of Planned Behavior (TPB) are researchers' references as a means of approach in analyzing e-Filing systems because the Technology Acceptance Model (TAM) refers to aspects of technology-based acceptance, while in Theory of Planned Behavior (TPB) refers in the aspect of acceptance based on user behavior in using something, Partial Least Square (PLS) is used to calculate and to release data so that it can measure user acceptance behavior in using e-Filing System based on a combination of two models
\end{abstract}

Keywords: Taxation, E-filing, TAM, TPB, PLS

\section{Pendahuluan}

Modernisasi pajak mulai diberlakukan guna untuk melaksanakan pelayanan perpajakan yang berbasis good governance dengan cara mengedepankan layanan perpajakan yang berbasis elektronik, inovasi seperti ini diharapkan menjadi sebuah solusi untuk memberikan layanan yang konsisten, efisien, tepat, berkualitas, fleksibel agar terwujudnya layanan sistem perpajakan yang nyaman dan aman bagi para Wajib Pajak. Perubahan mendasar mulai dirasakan dengan jenis pelayanan perpajakan berbasis elektronik yaitu para Wajib Pajak dapat menyampaikan surat pemberitahuan (SPT) dan penyampaian perpanjangan Surat Pemberitahuan (SPT) secara elektronik sistem tersebut adalah e-Filing. 
e-Filing merupakan layanan perpajakan yang berfungsi sebagai media penyampaian surat pemberitahuan kepada para Wajib Pajak melalui elektronik secara realtime dengan menggunakan internet ataupun bisa dilakukan lewat jasa penyedia aplikasi yang telah dipilih oleh Direktorat Jenderal Pajak (DJP) [1].Melalui penerapan e-Filing nantinya para pelaku pajak baik dari segi penyelenggara pajak ataupun para Wajib Pajak akan dimudahkan dalam segi sistem yang terkait penyampaian laporan kemudian melaporkan Surat Pemberitahuan (SPT) per tahunnya dengan penggunaannya yang sangat fleksibel, karena dengan sistem online e-Filing dapat digunakan dimanapun dan kapanpun asal terhubung ke jaringan internet. e-Filing sejatinya mempersingkat waktu sekaligus pengeluaran hal itu dikarenakan pada sistem elektronik seperti ini yang dibutuhkan hanyalah terhubung ke internet karena penyampaian SPT akan dapat dilakukan 24 jam termasuk tidak pada jam kerja hari dan bisa kita gunakan tanpa perlu repot ke kantor pelayanan pajak karena sistem sudah berbasis online. Para pengguna sistem e-Filing khususnya Wajib Pajak yang merasa bahwa e-Filing itu mudah mereka tentunya senantiasa akan menggunakan ketika mereka butuh kan sistem tersebut dan tentunya Para Wajib Pajak merasa bahwa sistem e-Filing itu berguna tentunya akan membuat rasa ingin terus mencoba sistem hingga sepenuhnya paham. Dengan begitu hal - hal yang masih kurang memadai di sistem tersebut akan terasa tak nampak sehingga menyebabkan para pengguna terlena dengan kelemahan sistem yang ada dan akan menggunakan sistem tersebut. Dari berbagai segi manfaat sistem nantinya akan memberikan rasa puas ketika menggunakan sistem . Pengguna sistem $e-$ Filing memberikan angka yang cukup signifikan dari segi sikap pengguna dalam penggunaan sistem [2].

Pada berbagai penelitian sebelumnya yang menggunakan model Technology Acceptance Model (TAM) mendapatkan hasil yang bermacam -macam, pengembangan model ini juga digunakan peneliti hanya sebatas dari penerimaan terhadap suatu teknologi informasi karena model ini pada dasarnya hanya berupa model penerimaan teknologi. [3]. Kesuksesan sistem informasi yang paling dominan disebabkan dari variabel kualitas penerimaan informasi dan kualitas penerimaan sistem oleh kepuasan pengguna. Kepuasan pengguna menjadi variabel yang sangat berpengaruh bagi variabel dampak penerimaan individu dan niat pengguna [4]. Namun dari kedua penelitian tersebut masih ditemukan adanya kekurangan karena tidak memperhitungkan perilaku pengguna dari e-Filing itu sendiri jadi hasil yang didapat kurang menjabarkan bagaimana e-Filing diterima secara perilaku pengguna.

Penelitian ini ditujukan untuk mengetahui hal-hal yang berkaitan dengan perilaku pengguna dan berbagai faktor yang berkaitan dengan penerimaan pengguna di sistem e-Filing karena berdasarkan penelitian sebelumnya penggunaan sistem masih tergolong sangat rendah dan kurang digunakan oleh masyarakat. Model gabungan TAM dan TPB merupakan konsep utama dengan pertimbangan bahwa Model TPB dan TAM dapat menjadi konsep untuk penelitian terhadap penggunaan suatu sistem baik dari penerimaan dari teknologi dan sikap pengguna [5].

\section{Metode Penelitian}

\subsection{Studi Literatur}

Studi Literatur dilakukan untuk mempelajari mengenai berbagai penelitian sebelumnya yang berkaitan dengan penelitian ini, dengan dilakukannya studi literatur diharapkan peneliti akan mendapatkan berbagai informasi yang berhubungan dengan sistem e-Filing, TAM, TPB, PLS yang tentunya sangat berhubungan erat dengan penelitian ini.

\subsection{Metode Yang Digunakan}

Metode yang ada pada penelitian ini adalah menggunakan perhitungan analisis menggunakan pendekaatan Structural Equational Modelling (SEM) berbasis metode Partial Least Square (PLS), variabel pada penelitian ini dibedakan menjadi dua yaitu: variabel independen dan Varibel dependen.

Variabel Indepen adalah variabel yang akan mempengaruhi variabel dependen adapun konsruk yang termasuk pada varibel ini adalah PEOU, SN, PBC, Varibel dependen merupakan varibel output atau variabel hasil dari variabel independen konstruk yang termasuk variabel dependen adalah PU, ATU dan BIUS. Gambar 1 menjelaskan mengenai variabel/kontruk yang digunakan pada penelitian yang berdasarkan gabungan metode antara Technology Acceptance Model (TAM) dengan Theory of Planned Behaviours (TPB).

REPOSITOR, Vol. 2, No. 1, Januari 2020: 87-98 


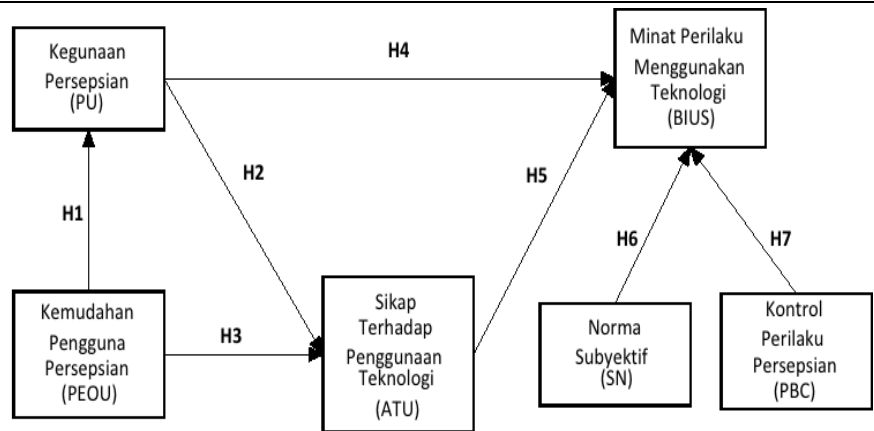

Gambar 1. Konstruk Penelitian

\subsection{Pengembangan Instrumen}

Pada tahap ini akan dikembangkan instrument penelitian yang berdasarkan pada varibel penelitian. Adapun tahapan pada pengembangan instrument adalah sebagai berikut:

\section{a. Domain Pengukuran}

Pada tahap ini menjelaskan indikator penelitian yang menjadi cakupan pada penelitian, adapun indikator yang ada pada penelitian ini adalah serangkaian gabungan dari metode TAM dengan TPB. Tabel 1 menjelaskan masing-masing konstruk beserta indikatornya pada penelitian ini.

Tabel 1. Indikator Konstruk Penelitian

\begin{tabular}{|c|c|c|}
\hline No & Konstruk & Indikator \\
\hline 1 & PU & $\begin{array}{l}\text { 1. Saya akan menemukan sistem yang berguna dalam pekerjaan saya } \\
\text { 2.Menggunakan sistem memungkinkan saya untuk menyelesaikan } \\
\text { pekerjaan lebih cepat } \\
\text { 3. Menggunakan sistem meningkatkan produktivitas saya } \\
\text { 4. Menggunakan sistem akan mengembangkan kinerja saya }\end{array}$ \\
\hline 2 & PEOU & $\begin{array}{l}\text { 1. Interaksi saya dengan sistem akan jelas dan dapat dimengerti } \\
\text { 2. Akan mudah bagi saya untuk terampil dalam menggunakan sistem } \\
\text { 3. Belajar mengoperasikan sistem sangat mudah bagi saya }\end{array}$ \\
\hline 3 & ATU & $\begin{array}{l}\text { 1.Menggunakan sistem adalah sebuah ide yang buruk/baik } \\
\text { 2.Sistem membuat pekerjaan menjadi lebih menarik } \\
\text { 3. Saya suka bekerja dengan menggunakan sistem }\end{array}$ \\
\hline 4 & SN & $\begin{array}{l}\text { 1. Orang-orang yang penting bagi saya berpikir bahwa saya harus } \\
\text { menggunakan sistem } \\
\text { 2. Manajemen yang senior dalam bisnis telah membantu dalam } \\
\text { penggunaan sistem } \\
\text { 3. Pada umumnya, organisasi telah mendukung penggunaan sistem } \\
\text { 4.Saya menggunakan sistem karena proporsi dari rekan kerja yang } \\
\text { menggunakan sistem }\end{array}$ \\
\hline 5 & BIUS & $\begin{array}{l}\text { 1. Saya berniat menggunakan sistem teknologi sesering yang dibutuhkan } \\
\text { 2. Bila memungkinkan, saya berniat tidak menggunakan sistem teknologi } \\
\text { 3. Sejauh mungkin, saya akan sering menggunakan sistem teknologi }\end{array}$ \\
\hline 6 & PBC & $\begin{array}{l}\text { 1. Saya mempunyai sumber daya yang diperlukan dalam menggunakan } \\
\text { sistem } \\
\text { 2. Memiliki pengetahuan untuk menggunakan sistem } \\
\text { 3. Orang tertentu (atau kelompok) tertentu tersedia untuk membantu } \\
\text { dengan kesulitan sistem } \\
\text { 4. Menggunakan sistem dengan gaya pekerjaan saya }\end{array}$ \\
\hline
\end{tabular}

\section{b. Instrumen Pengukuran}

Instrumen yang ada pada penelitian ini menggunakan tabel 1 yang menjelaskan mengenai indikator kontruk penelitian, Intrumen pengukuran pada penelitian ini juga diadaptasi berdarkan penelitian sebelumnya yang sudah ada, dikarenakan model gabunan antara TAM dengan TPB sudah sering digunakan pada penelitian sejenis. Total pernyataan yang digunakan berjumlah 22 yang tersusun berdasarkan konstruk yang terdapat pada kontruk penelitian. 
- Konstruk PEOU : 3 item pernyataan

- Konstruk PU : 4 item pernyataan

- Konstruk ATU : 3 item pernyataan

- Konstruk SN : 4 item pernyataan

- Konstruk BIUS : 3 item pernyataan

- Konstruk PBC : 4 item pernyataan

Susunan masing-masing pernyataan disusun berdasarkan indikator kontruk penelitian.

\section{c. Skala Pengukuran}

Pengukuran pada penelitian ini menggunakan skala likert dengan rentang skala 1-5 poin, adapun Skala Likert yang digunakan dalam penelitian ini berupa skala likert 5 poin yang dijelaskan melalui Tabel 2 [6]. Skala likert dapat digunakan untuk mengukur pendapat dan juga persepsi seseorang dalam penggunaan pada suatu sistem [7].

Tabel 2. Skala Pengukuran Likert

\begin{tabular}{clcc}
\hline \multirow{2}{*}{ No. } & \multicolumn{2}{c}{ Jawaban } & \multicolumn{2}{c}{ Nilai } \\
\cline { 3 - 4 } & Sangat Setuju & 5 & 1 \\
\hline 1 & (SS) & 4 & 2 \\
2 & Setuju (S) & 3 & 3 \\
3 & Ragu - ragu (RG) & 3 & 4 \\
4 & Tidak Setuju (TS) & 2 & 5 \\
5 & Sangat Tidak & 1 & 5 \\
\hline
\end{tabular}

\subsection{Pengumpulan Data}

Pengumpulan data yang dilakukan pada peneltian ini berupa survei karena masingmasing pertanyaan akan dibagikan kepada responden dengan cara kuisioner untuk menjawab setiap pertanyaanya. Peneliti akan membagikan secara langsung kepada responden sekaligus untuk membantu responden apa- apa saja yang berkaitan dengan variabel penelitian. Lokasi pengambilan data melalui responden dilakukan di KPP Pratama Malang Selatan. Adapun jumlah responden yang diambil berupa sampel dengan metode rumus slovin dihasilkan 100 responden, teknik sampling menggunakan metode simple random sampling sehingga keseluruhan responden dari populasi memiliki peluang yang sama besar untuk melakukan pengisian kuisioner [8]. Perhitungan jumlah sample menggunakan rumus Slovin karena dengan rumus ini cukup relevan dengan penelitian, perhitungan dijelaskan dengan Persamaan 1.

$$
n=\frac{N}{1+N e^{2}}
$$

Keterangan:

$\mathrm{e} \quad=$ Total sampel yang dihitung

$\mathrm{N} \quad=$ Total jumlah populasi penelitian

e $\quad=$ Signifikansi/prosentase kesalahan pada penelitian

\subsection{Analisa Data}

Penelitian ini menggunakan metode PLS sebagai alat untuk mengukur dan menilai masing-masing hubungan antar konstruk berdasarkan item pertanyaan yang ada dalam kuisioner. Metode PLS mempunyai beberapa kelebihan yang tentunya mendukung pada penelitian ini misalnya data tidak harus berdistribusi normal, tidak diperlukan data dengan jumlah yang sangat besar, kemudian PLS juga sebagai alat untuk mengkonfirmasi sebuah teori atau juga dapat menjelaskan ada tidaknya hubungan pada variabel laten [9]. Adapun tahapan analisis data dapat dijabarkan seperti penjelasan dibawah ini:

a. Perancangan Model Struktural (Inner Model)

Model ini dibentuk dengan tujuan untuk mengetahui hubungan antara masing-masing variabel pada penelitian, model ini dibuat berdasarkan rancangan kontruk penelitian yang ada di dalam penelitian.

REPOSITOR, Vol. 2, No. 1, Januari 2020: 87-98 
b. Perancangan Model Pengukuran (Outer Model)

Model pengukuran atau outer model adalah sebuah model yang menjabarkan dari model struktural yang ada dengan menghubungkan setiap intrumenya dan pada penelitian ini model pengkukurannya bersifat refleksif yang artinya arah hubungan mengarah dari varibel menuju indikator penelitian.

c. Evaluasi Outer Model

Model structural merupakan bagian dari outer model yang nantinya akan dihitung dnegan Convergent Validity, Discriminant Validity, dan Composite Reliability untuk mengukur tingkat keabsahannya. Evaluasi dari pengkuran outer model sendiri memiliki fungsi untuk menilai sejauh mana tingkat validitas dan juga tingkat reliabel dari masing-masing instrumen yang ada.

- Convergent validity diukur berdarkan korelasi nilai antara konstruk score dengan item score yang nilainya didapat dari kuisiner, kemudian untuk menilai apakah memiliki nilai yang tinggi dapat dilihat dari nilai loadinf faktor pada masing - masing intrumen, Nilai dikatakan tinggi jika berkorelasi lebih dari 0,70 namun untuk persoalan sistem yang masih dalam tahap pengembangan ukuran korelasi dapat dinilai dengan laoding faktor 0,50 sampai 0,60 sudah dinialai memadai. [10].

- Discriminant validity merupakan penilaian dengan cara mengukur dan melihat nilai cross loading dari masing- masing intrumen yang didapat dari pembagian kuisioner adapaun metode lain unutk menilai discrimant validity adalah dengan cara membandingkan nilai konstruk AVE dengan nilai masing - masing konstruk yang ada. Adapaun rumus dari AVE dapat dijabarkan dengan Persamaan 2.

$$
\mathrm{AVE}=\frac{\sum \lambda_{i}^{2}}{\sum_{i}^{2}+\sum l \operatorname{var}(\in i)}
$$

- Composite reliability digunakan untuk mengukur tingkat reliabel sebuah kuisioner dengan persamaan yang diajabarkan pada Persamaan 3.

$$
\rho \mathrm{C}=\frac{\left(\sum \lambda_{i}^{2}\right)}{\left(\sum \lambda_{i}^{2}\right)+\left(\sum l \operatorname{var}(\in i)\right)}
$$

Composite reliability dapat diukur dengan cara membandingkan nilai cronbanch alpha dengan nilai yang valid maka dapat dikatakan bahwa kuisiner tersebut reliabel dan layak. [10].

\section{d. Evaluasi Inner Model}

Model structural di uji menggunakan R-square, pada pengujian ini yang di uji adalah konstruk dependen saja, penilainya dilakukan dengan cara melihat tabel nilai dengan nilai $\mathrm{R}$ square kemudian dihitung apakah berpengaruh antara blok satu dnegan blok yang lainnya yang dievaluasi [10]. Untuk menguji nilai pada inner model dapat menggunakan persamaan 4.

$$
f^{2}=\frac{R_{\text {included }}^{2}-R_{\text {excluded }}^{2}}{1-R_{\text {included }}^{2}}
$$

\subsection{Pengujian Hipotesis}

Pengujian hipotesis adalah serangkaian model untuk menghubungkan varibel yang ada yaitu varibel pada konstruk eksogen dan juga endogen yang fungsinya untuk menilai keterkaitannya. Pengukuran hipotesa pada penelitian ini menggunakan resampling bootstrapping [10].Pengujian hipotesa pada penelitian ini menggunakan tabel nilai uji t, resampling dimungkinkan untuk menormalkan data agar data yang berbentuk atau terdistribusi bebas tidak perlu diasumsikan ke distribusi normal sehingga lebih mempercepat proses analisis. Dan dapat menghasilkan data yang repesentatif sesuai dengan total populasi penelitian.

\section{Hasil dan Pembahasan. \\ 3.1 Deskripsi Data}

Deskripsi data menjelaskan mengenai profil responden yang ada dan didapat melalui pembagaian kuisioner dalam penelitian. Profil responden dibagi berdasarkan jenis kelamin, usia, latar belakang pendidikan dan pekerjaan. 
a. Jenis Kelamin Responden

Tabel 3. Jenis Kelamin

\begin{tabular}{ccc}
\hline $\begin{array}{c}\text { Jenis } \\
\text { Kelamin }\end{array}$ & Jumlah & Presntase \\
\hline Laki-laki & 70 & $70 \%$ \\
Perempuan & 30 & $30 \%$ \\
\hline Total & 100 & $100 \%$ \\
\hline
\end{tabular}

Tabel 3 di atas dapat dilihat jumlah laki laki yang menjadi responden dalam penelitian ini lebih besar yaitu $70 \%$ sedangkan sisanya $30 \%$ di tempati oleh jenis kelamin perempuan.

b. Usia Responden

\begin{tabular}{ccc}
\multicolumn{3}{c}{ Tabel 4. Usia } \\
\hline Usia & Jumlah & Prosentase \\
\hline <25 TAHUN & 0 & $0 \%$ \\
25- 35 TAHUN & 33 & $33 \%$ \\
36-45 TAHUN & 32 & $32 \%$ \\
46-55 TAHUN & 21 & $21 \%$ \\
> 55 TAHUN & 14 & $14 \%$ \\
\hline Total & 100 & $100 \%$ \\
\hline
\end{tabular}

Pada Tabel 4 di atas dapat dilihat bahwa responden yang berusia antara 25 - 35 tahun berkisar $33 \%$, sedangkan 36 - 45 tahun berkisar $32 \%$, kemudian responden $64-55$ tahun berkisar $21 \%$ dan sisanya $14 \%$ di isi oleh responden yang berusia lebih dari 55 tahun.

c. Jenis Pekerjaan Responden

Tabel 5. Pekerjaan

\begin{tabular}{ccc}
\hline Pekerjaan & Jumlah & Prosentase \\
\hline PNS & 45 & $45 \%$ \\
Pegawai & 25 & $25 \%$ \\
Swasta & 29 & $29 \%$ \\
Wiraswasta & 1 & $1 \%$ \\
Lainnya & 100 & $100 \%$ \\
\hline Total & 100 \\
\hline
\end{tabular}

Dari Tabel 5 diatas dapat dilihat bahwa PNS menempati jumlah terbesar pada penelitian ini berkisar $45 \%$, kemudian Wiraswasta menempati peringkat kedua dengan jumlah $29 \%$ dan disusul oleh pegawai swasta $25 \%$ dan sisanya $1 \%$ di isi oleh pekerjaan lainnya.

d. Latar Belakang Pendidikan Responden

\begin{tabular}{ccc}
\multicolumn{3}{c}{ Tabel 6. Latar Belakang Pendidikan } \\
\hline Pendidikan & Jumlah & Prosentase \\
\hline SMP & 0 & $0 \%$ \\
SMA & 15 & $15 \%$ \\
Diploma & 3 & $3 \%$ \\
Sarjana & 81 & $81 \%$ \\
Magister & 1 & $1 \%$ \\
\hline Total & 100 & $100 \%$ \\
\hline
\end{tabular}

Dari Tabel 6 diatas dapat dijelaskan bahwa pendidikan sarjana menempati peringkat pertama dengan $81 \%$ kemudian $15 \%$ SMA dan $3 \%$ diploma kemudian $1 \%$ magister. Prosentase 
tersebut menjelaskan seberapa banyak responden yang mengisi pada penelitian ini berdasarkan latar belakang pendidikan.

\subsection{Analisa Data}

\section{a. Merancang Inner Model}

Perancangan inner model pada Gambar 2 dibentuk berdasarkan model dari kontruk penelitian.

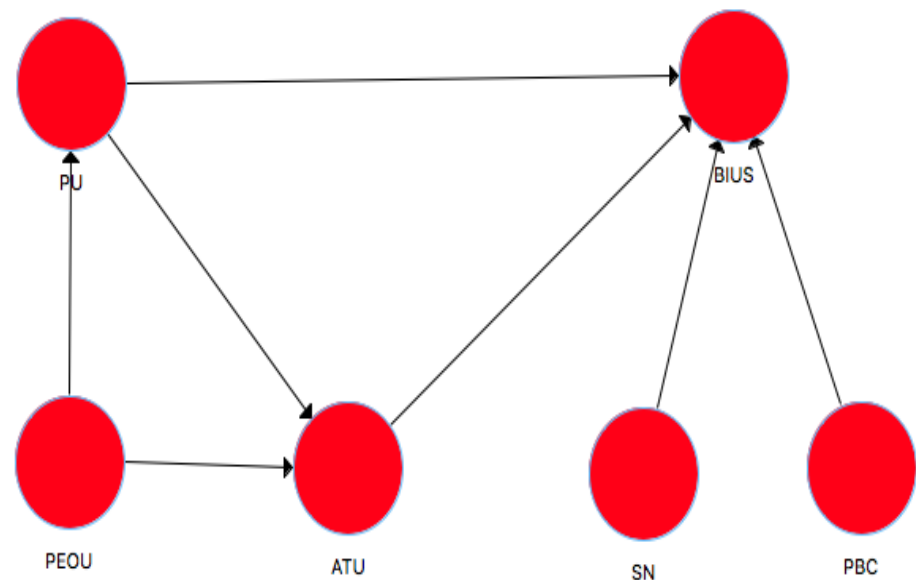

Gambar 2. Inner Model

\section{b. Merancang Outer Model}

Pada Gambar 3, outer model dibentuk berdasarkan masing-masing indikator yang terdapat pada masing-masing konstruk PBC, PEOU, SN, PU, ATU, BIUS. Outer model pada penelitian ini bersifat refleksif dengan arah panah dari kontruk menuju indikator.

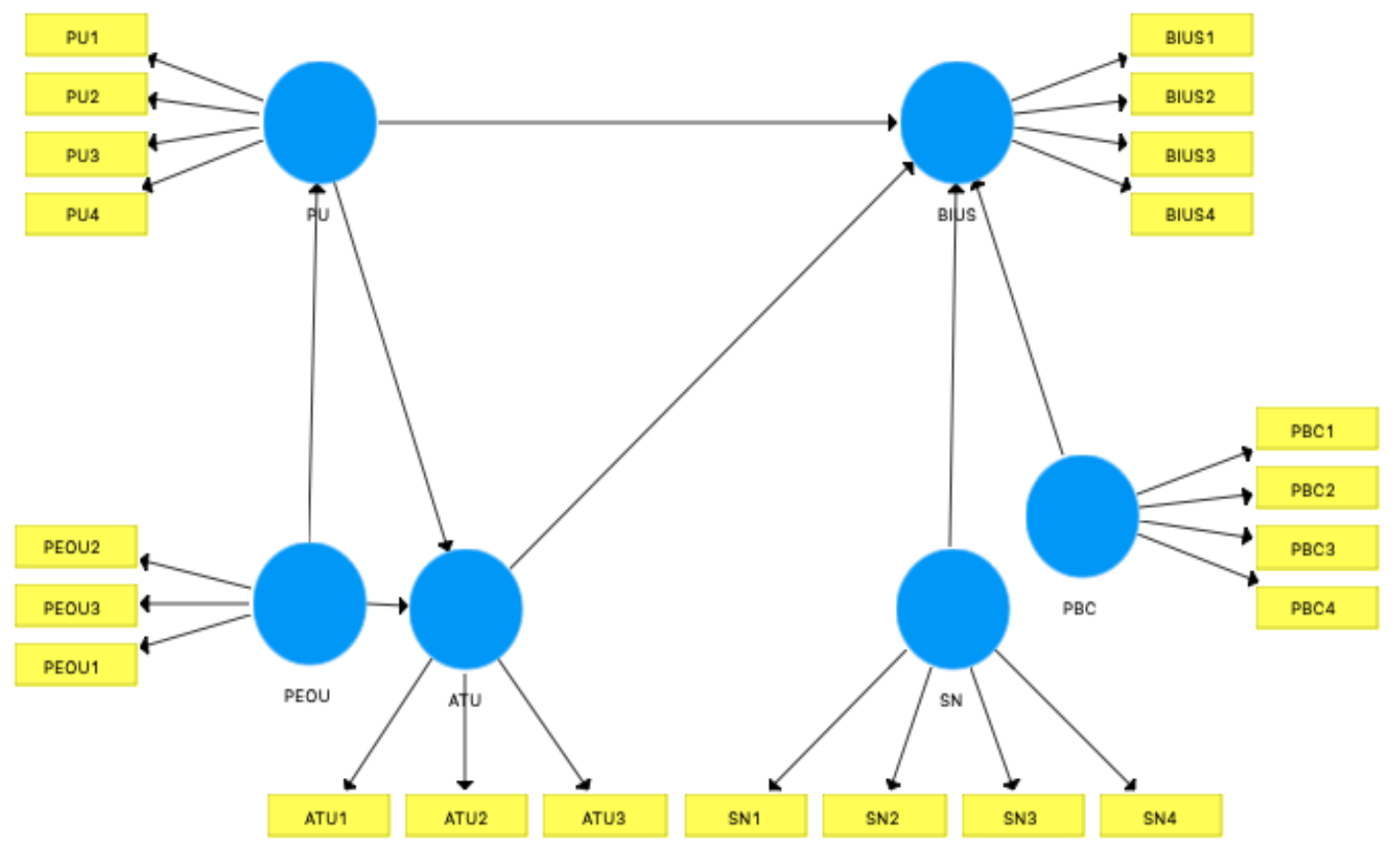

Gambar 3. Outer Model

\section{c. Evaluasi Outer Model}

Pada penelitian ini menggunakan bantuan software SmartPLS, estimasi model dilakukan dengan cara menguji nilai masing-masing indikator yang terdapat pada penelitian. Nilai dengan indikator model refleksif dapat dikatakan tinggi jika nilai kriteria ukuran refleksif individual memiliki nilai yang lebih besar dari 0,70 dengan kontruk yang diukur. Tetapi, nilai dengan loading factor 
antara 0,50 sampai 0,60 dapat dipertahankan untuk sistem yang masih dalam tahap pengembangan.

Pada hasil estimasi model dapat disimpulkan bahwa model dapat dilakukan evaluasi ke tahap selanjutnya dikarenakan pada eksekusi nilai korelasi pada tiap-tiap indikator memiliki loading faktor lebih dari 0,6.

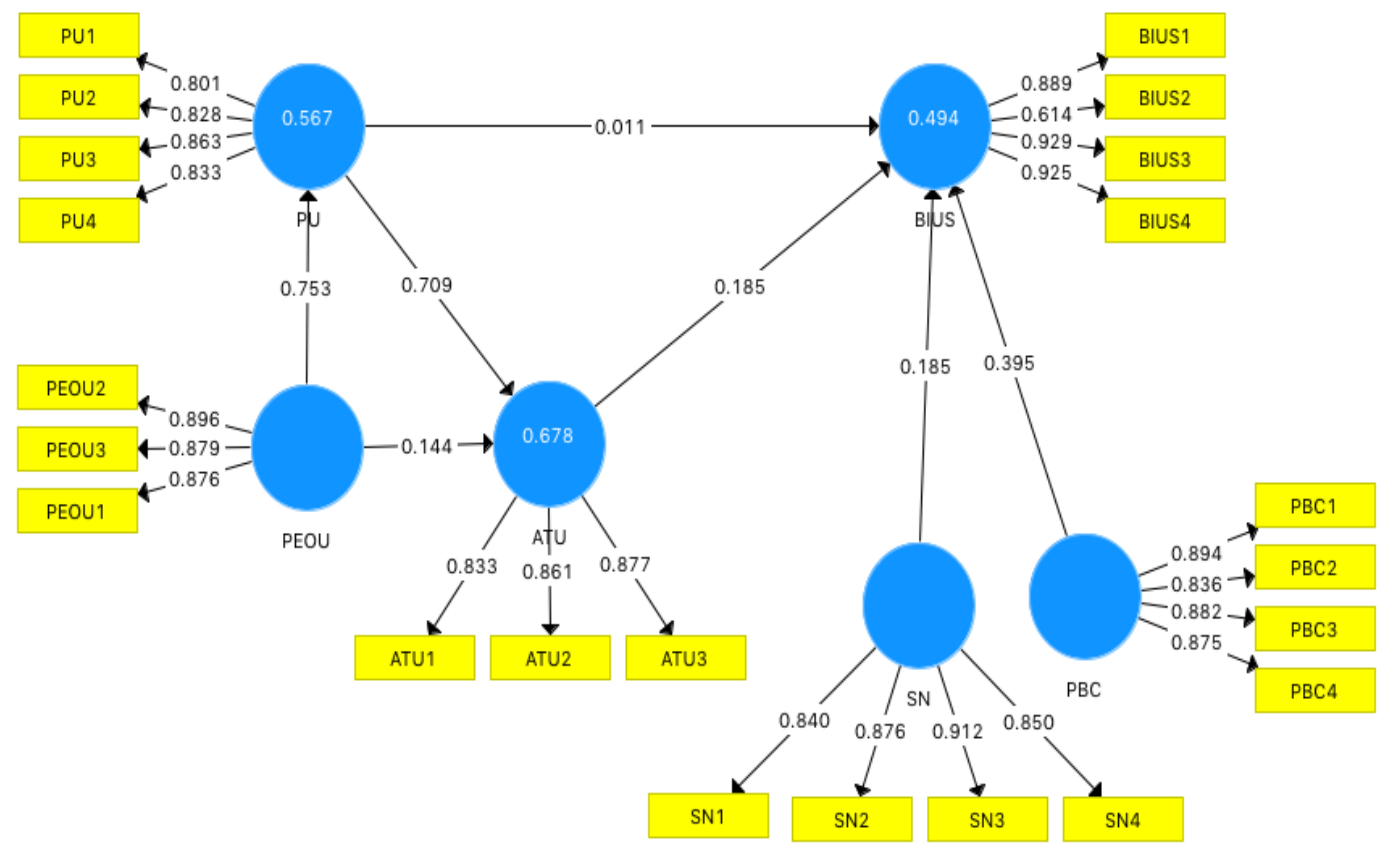

Gambar 4. Loading Faktor

Evalusi model dengan indikator refleksif dapat dilakukan dengan tiga cara yaitu Convergent Validity, Discriminant Validity, dan Composite Reliability.

Convergent Validity dapat dilihat dari hubungan korelasi konstruk dengan indikatornya (loading factor) untuk hasil dari masing-masing indikator dapat dilihat melalui Gambar 4.

Discriminant validity dapat diukur melalui tabel Cross loading, jika nilai indikator pada masing-masing konstruk lebih tinggi daripada indikator pada kontruk lain dapat dikatakan kontruk laten dapat memprediksi lebih baik di bloknya darpida di blok yang lain, hal tersebut dapat dilihat melalui tabel

Setelah dilakukan pengujian validitas kontruk yaitu Convergent Validity, Discriminant Validity kemudian dilakukan dengan pengujian reliabilitas kontruk dengan cara Composite Reliability dan Cronbacnh Alpha. Kontruk dikatakan reliabel jika nilai yang mengukur pada masing- masing konstruk diatas 0,70 . Jika dilihat bedasarkan tabel dapat dikatakan bahwa masing-masing kontruk sudah reliabel karena nilainya diatas 0,70 .

\section{d. Evaluasi Inner Model}

Setelah dilakukan pengujian outer model kemudian dilakukan pengujian inner model dengan melihat nilai R-square pada konstruk endogen pada penelitian. Adapun persyaratan nilai dari R-square yang harus dipenuhi yaitu: Model struktural yang memiliki hasil R-square sebesar 0,67 mengindikasikan bahwa model "baik", R-square sebesar 0,33 mengindikasikan bahwa model "moderat", dan Rsquare sebesar 0,19 mengindikasikan bahwa model "lemah". Melaui tabel 3 dapat dilihat nilai R-square pada masing masing konstruk endogen.

Tabel 7. Nilai R-Square

\begin{tabular}{cc}
\hline & R Square \\
\hline ATU & 0,678 \\
BIUS & 0,494 \\
PU & 0,567 \\
\hline
\end{tabular}

REPOSITOR, Vol. 2, No. 1, Januari 2020: 87-98 
Penjelasan dari Tabel 7 di atas akan di jabarkan sebagai berikut:

- Pada konstruk endogen ATU mempunyai nilai R-square (R2) 0,678 yang berarti konstruk endogen ATU dapat dijelaskan oleh konstruk PU dan PEOU hanya sebesar $67 \%$ dan $37 \%$ pada variabel lain yang ada di luar model menjelaskan sisanya.

- Pada konstruk endogen BIUS mempunyai nilai R-square (R2) 0,494 yang berarti konstruk endogen BIUS dipengaruhi oleh konstruk ATU, SN, PBC dan PU kemudian sisanya dijabarkan oleh variabel lain yang terdapat di luar permodelan. dapat dijelaskan oleh konstruk PU dan PEOU hanya sebesar $49 \%$ dan variabel lain yang ada di luar model menjelaskan sisanya.

- Pada konstruk endogen PU mempunyai nilai R-square (R2) sebesar 0,567 yang berarti bahwa konstruk endogen PU dipengaruhi oleh konstruk PEOU sebesar 56\% yang kemudian sisanya dijabarkan oleh variabel lainnya di luar pemodelan.

\subsection{Pengujian Hipotesis}

Pengujian hipotesis pada penelitian ini menggunakan metode resampling bootstrapping, bootstrapping ini sebenarnya memiliki fungsi sebagai meminimalkan masalah ketidaknormalan data dalam suatu penelitian. Resampling bootsrapping sendiri menggunakan software smartPLS sebagai salah satu cara untuk menilai sebuah data dalam penelitian.

Pengujian statistik yang digunakan dalam penelitian ini menggunakan statistik $t$ atau pengujian $t$, fungsi dari uji $t$ sendiri adalah untuk mengukur sejauh mana perbandingan pada varibel bebas terhadap varibel terikat. Pengujian ini membandingkan nilai hitung $t$ dengan $t$ tabel yang diambil berdasarkan taraf signifikansi. nilai derajat kebebasan pada t-tabel dengan angka 97 dengan taraf signifikansi sebesar $5 \%$ sehingga diperoleh nilai t 1,985. Kemudian setelah ditentukan nilai t-tabel maka dilakukan pengujian hipotesis yang ditampilkan berdasarkan nilai path coefficient yang telah dilakukan resampling bootstrapping pada data.

\begin{tabular}{cccc}
\multicolumn{4}{c}{ Tabel 8. Pengujian Hipotesis } \\
\hline & $\begin{array}{c}\text { Original } \\
\text { Sample (O) }\end{array}$ & $\begin{array}{c}\text { TStatistics } \\
(\mid \text { OSTERR|) }\end{array}$ & Keterangan \\
\hline ATU -> BIUS & 0,185 & 1,115 & Ho Ditolak \\
PBC -> BIUS & 0,395 & 2,350 & Ho Diterima \\
PEOU -> ATU & 0,144 & 1,283 & Ho Ditolak \\
PEOU -> PU & 0,753 & 13,150 & Ho Diterima \\
PU -> ATU & 0,709 & 7,723 & Ho Diterima \\
PU -> BIUS & 0,011 & 0,055 & Ho Ditolak \\
SN -> BIUS & 0,185 & 1,488 & Ho Ditolak \\
\hline
\end{tabular}

Berdasarkan hasil pengujian hipotesis pada Tabel 8 dapat disimpulkan bahwa ada 3 hipotesis yang diterima, jika kita nilai hasil dari pengujian hipotesis yang telah dilakukan maka bisa disimpulkan ada 3 hipotesis yang sesuai dan 4 hipotesis lainnya ditolak.

Hipotesis yang sesuai yaitu:

- $\mathrm{PBC}->$ BIUS

- PEOU -> PU

- PU $\rightarrow$ ATU

Sedangkan ada 3 hipotesis yang ditolak yaitu:

- ATU -> BIUS

- PEOU ->ATU

- $\mathrm{PU} \rightarrow \mathrm{BIUS}$

- $\mathrm{SN}->$ BIUS

\subsection{Pembahasan Hasil Penelitian}

- Dampak pengaruh konstruk ATU kepada konstruk BIUS

Dari hasil pengujian yang telah dilakukan berupa resampling bootstrapping dapat disimpulkan nilai path coefficient kurang memenuhi karena hanya 1,115 sedangkan kriteria dari t-tabel yang diharapkan adalah 1,985 sehingga hipotesa ini dinilai kurang signifikan. Sedangkan untuk nilai koefisien variabel barada pada angka 0,185 sehingga dapat diartikan bahwa nilai koefesien variabel dari ATU terhadap BIUS sebesar 0,185 yang itu berarti berpengaruh sekitar 18,5\%. Dampak ATU kepada BIUS diartikan sebagai sikap dari para pengguna sistem , semakin tinggi nilai yang didapatkan dari sikap dalam penggunaaan teknoogi maka juga berkaitan dengan 
minat perilaku dalam menggunakan sebuah teknologi. Jadi sikap seseorang untuk menggunakan sebuah teknologi memiliki pengaruh yang cukup signifikan terhadap minat perilaku pengguna.

- Dampak pengaruh konstruk PBC kepada konstruk BIUS

Dari hasil pengujian yang telah dilakukan sebelumnya dapat dinilai melalui nilai path coefficient yang sudah memenuhi kriteria dengan nilai 2,350 dari kriteria t-tabel yang diharapkan adalah 1,985 sehingga hipotesa ini dinilai cukup signifikan. Sehingga konstruk PBC akan mempengaruhi konstruk BIUS sebesar $39,5 \%$ sesuai dengan nilai koefisien variabel yang berada pada angka 0,395 . Semakin tinggi nilai yang didapat maka dapat diartikan pengguna memiliki sikap yang baik dalam menggunakan sistem e-Filing. Kontrol perilaku dalam hal ini berkaitan dengan kontrol persepsi seseorang dalam menggunakan suatu sistem.

- Dampak pengaruh konstruk PEOU kepada konstruk ATU

Dari hasil pengujian yang telah dilakukan dengan cara resampling bootstrapping dapat disimpulkan nilai path coefficient kurang memenuhi karena hanya 1,283 sedangkan kriteria dari t-tabel yang diharapkan adalah 1,985 sehingga hipotesa ini dinilai kurang signifikan. Sedangkan untuk nilai dari koeffisien variabel laten yang didapat dari path coefficient yaitu bernilai 0,144 sehingga dapat diartikan bahwa berpengaruh sekitar $14,4 \%$ variabel PEOU kepada variabel ATU. Pengaruh kemudahan untuk menggunakan teknologi tidak berpengaruh cukup besar kepada sikap terhadap penggunaan teknologi, hal itu mungkin dikarenakan masih banyak orang yang awam mengenai inovasi teknologi yang kian hari kian mengalami perkembangan. Khususnya untuk pelaporan pajak yang tidak secara manual yaitu dnegan menggunakan kertas namun sudah tergantikan dengan sistem e-Filing

- Dampak pengaruh PEOU kepada konstruk PU

Dari hasil pengujian yang telah dilakukan sebelumnya dapat diartikan bahwa nilai path coefficient sangat memenuhi karena mempunyai nilai 13,150 dari kriteria t-tabel yang diharapkan adalah 1,985 sehingga hipotesa ini dinilai sangat baik. Sedangkan untuk nilai koefisien variabel latennya yang didapat dari patth coeficient sebesar 0,753 sehingga dapat diartikan bahwa berpengaruh sekitar $75 \%$ variabel PEOU terhadap PU. Jadi semakin tinggi nilai konstruk persepsi kemudahan penggunaan maka selaku pengguna semakin merasa bahwa sistem itu memiliki banyak kegunaan. Jika dipersepsikan maka sistem e-Filing memiliki kemudahan penggunaan sehingga pengguna akan lebih banyak mendapat manfaat saat menggunakan e-Filing. Karena sistem tersebut dapat melaporkan surat pemberitahuan dengan cepat, bisa dimana saja dan kapanpun saat pengguna membutuhkan, sehingga pengguna sistem merasa bahwa sistem sangat bermanfaat bagi kinerja dan produktifitas mereka dalam segi pelaporan SPT tahunan.

- Dampak pengaruh konstruk PU kepada konstruk ATU

Berdasrakan pengujian hipotesis yang telah dilakukan sebelumnya dapat dijelaskan dengan melihat nilai path coefficient sudah memenuhi karena mencapai 7,723 sedangkan kriteria dari t-tabel yang diharapkan adalah 1,985 sehingga hipotesa ini dinilai berpengaruh sangat signifikan. Sedangkan untuk nilai koeffisien variabel latennya yang didapat dari path coefficient bernilai 0,709 hal itu dapat diartikan bahwa berpengaruh sekitar $70 \%$ variabel PU terhadap ATU. Semakin baik manfaat yang dapat diberikan sebuah sistem baik dari segi fungsi maupun performa yang secara tidak langsung akan memberikan kepuasaan bagi pengguna untuk menggunakan sistem itu sendiri. Jika dipersepsikan maka pengguna merasa bahwa sistem eFiling sangat bermanfaat dalam segi manfaat sehingga banyak para Wajib Pajak senang dan berperilaku baik terhadap kepatuhan dalam menggunakan sistem itu sendiri.

- Dampak pengaruh konstruk PU kepada konstruk BIUS

Dari hasil pengujian hipotesiss yang dilakukan sebelumnya dapat ditarik kesimpulan dengan melihat nilai path coefficient kurang memenuhi karena hanya 0,055 sedangkan kriteria dari t-tabel yang diharapkan adalah 1,985 sehingga hipotesa ini dinilai kurang signifikan. Sedangkan untuk nilaai koeffisien variabel latennya yang didapat dari patth coeficient bernilai 0,011 sehingga dapat diartikan bahwa berpengaruh sekitar $1,1 \%$ variabel PU terhadap BIUS. Jika dilihat dari segi kegunaan persepsian sistem e-Filing bisa dikatakan sudah cukup baik karena sudah memenuhi batas signifikan, namun masih belum mempengaruhi penggunaan dari segi minat dan perilaku pengguna. Hal itu bisa dikarenakan sistem e-Filing hanya mengacu pada segi pelaporan SPT tahunan saja dan tidak memiliki fungsi lain daripada itu. Meskipun jika dilihat nilai kebermanfaatan berpengaruh cukup besar namun tidak memiliki pengaruh yang signifikan terhadap penggunaan sistem e-Filing.

REPOSITOR, Vol. 2, No. 1, Januari 2020: 87-98 
- Dampak pengaruh konstruk SN kepada konstruk BIUS

Dari hasil pengujian menggunakan pengujian resampling bootstrapping dapat dinilai path coefficient kurang memenuhi karena hanya 1,488 sedangkan kriteria dari t-tabel yang diharapkan adalah 1,985 sehingga hipotesa ini dinilai kurang signifikan. Sedangkan untuk nilai koeffisien varabel latennya yang didapat dari path coeficient bernilai 0,185 sehingga dapat diartikan bahwa berpengaruh sekitar $18,5 \%$ variabel SN terhadap BIUS. Dari hal tersebut dapat diartikan bahwa pengaruh sosial sedikit memengaruhi dalam penggunaan pada sistem ini e-Filing.

\section{Kesimpulan}

Berdasarkan hasil penelitian yang telah dipaparkan sebelumnya maka didapat beberapa kesimpulan sebagai berikut:

1. Sistem e-Filing memiliki taraf signifikansi yang baik mulai dari segi kontrol perilaku, tingkat kegunaan, tingkat kemudahan dan perilaku sosial.

2. Sistem e-Filing sedikit memiliki kelemahan yaitu pada segi kemudahan penggunaan dan perilaku pengguna namun nilainya dapat dikatakan cukup baik hanya saja pada sikap penggunaan sistem yang memiliki nilai kurang.

3. Sistem e-Filing dapat dikatakan sukses dalam pelaksanaanya sebagai penerimaan SPT tahunan karena dari segi kontrol perilaku, tingkat kegunaan, tingkat kemudahan dan perilaku sosial sudah mendukung kinerja dari sistem e-Filing itu sendiri.

4. Minat pengguna sistem ini sendiri cukup baik karena segi kemudahan penggunaan dan perilaku pengguna sudah mempengaruhi pengguna sistem hanya saja sikap pengguna terhadap sistem itu sendiri yang kurang memuaskan karena ada segi paksaan dari Direktorat Jenderal Pajak karena mewajibkan para Wajib Pajak untuk menggunakan sistem e-Filing sebagai media penyampaian laporan SPT tahunan sebagai pengganti pelaporan SPT secara konvensional.

\section{Referensi}

[1] "Penyampaian Surat Pemberitahuan Online (eFiling)," [Online]. Available: http://www.pajak.go.id/content/penyampaian-surat-pemberitahuan-online-efiling.

[2] S. Wiyono, "Evaluasi Penerimaan Wajib Pajak terhadap Penggunaan E-filling sebagai Sarana Pelaporan Pajak secara Online dan Realtime," Jurnal Riset Akuntansi Indonesia, vol. 11, pp. 117-132, 2008.

[3] D. F. Dets, "Perceived Usefulness, Perceived Ease of Use, and Acceptance of Information System Technology," MIS Quarterly, vol. 13, pp. 319-339, 1989.

[4] E. R. McLean and W. DeLone, "The DeLone and McLean Model of Information System Success," Journal of MIS, pp. 9-30, 2003.

[5] R. Oktapiani, "Interpretasi Model Penerimaan Sistem Ujian Online Dengan Pendekatan Technologi Acceptance Model (Tam) Dan Theory Planned of Behavior (Tpb) Di Smk Pasim Plus Kota Sukabumi," SWABUMI, vol. 5, pp. 1-9, March 2017.

[6] W. W, "Pengembangan Skala Psikologi: Lima Kategori Respons ataukah Empat Kategori Respons?," Yogyakarta, 2010.

[7] S. P. D, Metode Penelitian Pendidikan Penelitian Kuantitatif dan Kualitatif, Bandung: Alfabeta, 2010.

[8] Nurhayati, "Studi Perbandingan Metode Sampling Antara Simple Random dengan Statified Random," Jurnal Basis Data, vol. 3, Mei 2008.

[9] M. Ulum, I. M. Tirta and D. Anggraeni, "Analisis Structural Equation Modeling (SEM) Untuk Sampel Kecil dengan Pendekatan Partial Least Square (PLS)," Prosiding Seminar Nasional Matematika, November 2014.

[10] Ghozali, Structural Equation Modeling, Metode Alternatif dengan Partial Least Square, Badan Penerbit Universitas Diponegoro, 2011. 
REPOSITOR, Vol. 2, No. 1, Januari 2020: 87-98 